\title{
Strategies for prevention of ultrasound-guided prostate biopsy infections [Erratum]
}

\author{
Lu DD, Raman JD. Infect Drug Resist. 2016;9:161-169
}

On page 168, Reference section, an error occurred with some of the numbering, relating to:

15. Berger AP, Gozzi C, Steiner H, et al. Complication Rate of transrectal ultrasound guided prostate biopsy: a comparison among 3 protocols with 6, 10 and 15 cores. $J$ Urol. 2004;171(4):1478-1481.

16. Jeon SS, Woo S-H, Hyun J-H, Choi HY, Chai SE. Bisacodyl rectal preparation can decrease infectious complications of transrectal ultrasound-guided prostate biopsy. Urology. 2003;62(3):461-466.

17. Pepe P, Aragona F. Morbidity after transperineal prostate biopsy in 3000 patients undergoing 12 vs 18 vs more than 24 needle cores. Urology. 2013;81(6):1142-1146.

18. Loeb S, Carter HB, Berndt SI, Ricker W, Schaeffer EM. Is repeat prostate biopsy associated with a greater risk of hospitalization? Data from SEER-Medicare. J Urol. 2013;189(3):867-870.

This should have in fact been:

16. Berger AP, Gozzi C, Steiner H, et al. Complication Rate of transrectal ultrasound guided prostate biopsy: a comparison among 3 protocols with 6, 10 and 15 cores. $J$ Urol. 2004;171(4):1478-1481.

17. Jeon SS, Woo S-H, Hyun J-H, Choi HY, Chai SE. Bisacodyl rectal preparation can decrease infectious complications of transrectal ultrasound-guided prostate biopsy. Urology. 2003;62(3):461-466.

18. Pepe P, Aragona F. Morbidity after transperineal prostate biopsy in 3000 patients undergoing 12 vs 18 vs more than 24 needle cores. Urology. 2013;81(6):1142-1146.

19. Loeb S, Carter HB, Berndt SI, Ricker W, Schaeffer EM. Is repeat prostate biopsy associated with a greater risk of hospitalization? Data from SEER-Medicare. J Urol. 2013;189(3):867-870.

Numbering within the main text relates to this corrected referencing order.

\section{Publish your work in this journal}

Infection and Drug Resistance is an international, peer-reviewed openaccess journal that focuses on the optimal treatment of infection (bacterial, fungal and viral) and the development and institution of preventive strategies to minimize the development and spread of resistance. The journal is specifically concerned with the epidemiology of antibiotic

\section{Dovepress}

resistance and the mechanisms of resistance development and diffusion in both hospitals and the community. The manuscript management system is completely online and includes a very quick and fair peerreview system, which is all easy to use. Visit http://www.dovepress.com/ testimonials.php to read real quotes from published authors.

Submit your manuscript here: https://www.dovepress.com/infection-and-drug-resistance-journal 